This question is the subject of a short communication to the Astrophysical journal, September, vol. xl., No. 2, by Dr. C. E. Kenneth Mees, of the Kodak Research Laboratory, who, thinking that the cause was due to a change in humidity, made experiments to determine the effect of varied humidity on the sensitiveness and development factor of Seed 23 and Seed 30 plates. Experimenting within a range of 0.5 to 85 ver cent. of humidity, and giving the emulsion film time to come into equilibrium with the air, he found that both sensitiveness and development factor decreased about 25 per cent. when the humidity was increased from 0.5 to 85 per cent. This result seems very conclusive, and shows the restraining action of a change of moisture on the sensitiveness of photographic film. Dr. Mees suggests that all photographic materials used for photometric work should be brought previously into equilibrium with the atmosphere in which they are to be used.

Tests of a 24-in. OBjective.-At the end of the year I9I the erection of a 24 -in. refractor was completed for the Sproul Observatory, U.S.A. The objective was made by Brashear, the crown disc being furnished by the Parra-Mantois firm of Paris, and the flint disc by Schott and Genossen, of Jena. In Igr2 the objective underwent a series of tests at the hands of Profs. John A. Miller and Ross W. Marriott, who used the method of extra-focal images devised by Hartmann. In 1913 a final series of tests was made, and this, with the foregoing, are described by the authors in the October number (vol. clxxviii., No. 4, p. 465) of the Journal of the Franklin Institute. It seems that in the first tests measures of photographs of star images taken through a screen containing circular holes showed certain discrepancies among the focal distances of different parts and zones of the lens, which, while not excessive, were absent before the mounting of the lens. The cause of these discrepancies was traced to a side pressure spring to prevent the objective from sliding in its cell. After a reduction of the pressure further tests were completed with screens containing different numbers of holes. The result was to show that "from every standpoint the lens is an excellent one."

\section{THE RECTORSHIP OF THE UNIVERSITY} OF GLASGOW.

THE matriculated students of the University of Glasgow, divided into four "nations" under the ancient constitution derived from Bologna and Paris, have unanimously elected M. Raymond Poincaré, President of the French Republic, and member of the academy, to be their rector for a term of three years. For a long time past the recurring elections to the rectorship have been conducted on purely political lines, and the result was always hailed as a party triumph for one side or the other. Mr. Disraeli (I87I) was succeeded by $\mathrm{Mr}$. Gladstone (I877), and Mr. Bright (1880); Mr. A. J. Balfour (I890), Mr. J. Chamberlain (1896), Lord Rosebery (1899), Mr. Asquith (1905), and Lord Curzon (I908), were followed by Mr. Birrell (IgII).

Before the present national crisis arose, Lord Strathclyde, Mr. Bonar Law, and Mr. R. B. Cunninghame Graham had been selected as their champions by the several political groups. But the students speedily recognised that in the actual situation of the country a party contest was out of place, and the candidates first chosen were withdrawn. The political leaders thereupon, in token of "the close bond of union between France and Great Britain," addressed a joint invitation to M. Poincaré, which the President was pleased to accept. The proposal was received with No. 2348 , vOL. 94] enthusiasm, and unanimously endorsed by the students. In the absence of any other nomination, the Principal, Sir Donald MacAlister, K.C.B., on behalf of the Senate, at noon on Saturday, October 24, declared M. Poincaré duly elected by the votes of all the "nations."

The rector is the official President of the University Court. $\mathrm{He}$ appoints an assessor, who is ex officio a member of the governing body. $\mathrm{He}$ is " installed," and delivers a rectorial address, at a solemn assembly of the University during the period of his tenure. Otherwise his position is honorary. In the present case the "installation "will have to await the termination of the war.

The names of two relatives of the new rector, Dr. Henri Poincaré and Dr. Boutroux, already appear on the University's roll of honorary graduates. From the beginning of the sixteenth century onwards a Glasgow graduate has from time to time been chosen as rector of the University of Paris. This is the first occasion on which a French scholar has held the rectorship of Glasgow.

\section{THE ROYAL ANTHROPOLOGICAL INSTITUTE.}

PROF. ARTHUR KEITH publishes in the Journal of the Royal Anthropological Institute for January-June, 19I4, his presidential address on the reconstruction of fossil human skulls. This is, to a large extent, the outcome of the controversy which arose on the reconstruction of the Piltdown skull, in which his scheme differed from that suggested by Dr. Smith Woodward. As a practical test of his methods Prof. Keith invited Dr. Douglas Derry to furnish him with fragments of a specimen skull, which he engaged to reconstruct and to publish the results of his experiment, whatever might be the result. The reconstruction of this skull by Prof. Keith so closely, in his opinion, resembles the cast of the original skull from which the fragments were taken as to confirm the validity of his methods. He is thus led to deny that the architecture of the human skull lies outside the limits of true science. He asserts that it is framed according to definite principles, that all its parts are correlated, and that it is possible from a part-if our knowledge is accurate and full-to reconstruct the whole. The address marks a decided advance in our knowledge of the science of craniometry.

Mr. Henry Balfour contributes to the journal an interesting paper on the art of fire-making with a flexible sawing-thong. This method of fire-production has been traced in three distinct localities: an eastern area extending from Assam to New Guinea; by Miss Mary Kingsley among the Ba-Kele of the Ogowe River in West Africa; and in Sweden, Germany, and Russia, where it is used as a means of procuring needfire. This strange distribution of the art raises many interesting questions, particularly in relation to the theories of Graebner and his school, who postulate the derivation of these and similar ideas from a single well-defined area, whence they are generally transmitted. In the eastern area it seems to be associated with the Negrito culture, and is possibly a variant of the better known rigid, blade-like fire-saw. In Africa, again, an independent origin is strongly suggested, although the possibility of transmission from the east cannot be quite ignored. In Europe the theory of transmission from the Negritic, Indonesian, pre-Malayan, or Bantu culture can be accepted only with much reservation, and here, too, the inference is that it was independently discovered. Much still remains to be done by examining museum specimens and by the collection 
of examples from other parts of the world. Mr. Balfour pleads for assistance in adding to the fine collection of material in his charge in the Pitt-Rivers Museum, Oxford.

The journal also contains an elaborate, well-illustrated paper on the antiquity of man in Ireland as traceable in the older series of flint implements. Needless to say, the character of some of the specimens obtained from the raised beach at Larne and other sites in North Ireland has formed the subject of active controversy, $\mathrm{Mr}$. Knowles asserting that they are human artefacts, while other authorities, as in the case of the eoliths, deny that they are the work of man. In this paper Mr. Knowles urges the validity of his theory with much vigour, and he recognises in some specimens striæ which prove that they belong to the Ice age. He sees in some of them a remnant saved from the precursors of the Chellean and Achulean coups de poing of France and the south of England. His arguments deserve serious attention, but it is perhaps too much to say that he will succeed in convincing his opponents.

The institute under its present management has made a decided advance. Its members now number 534-the highest point hitherto attained-as compared with 367 in 1913. During the year it has been engaged in various schemes of research, and has strongly advocated the teaching of anthropology to candidates for the Indian and Colonial Civil Services. But a larger membership is much to be desired, because many important projects, and, in particular, the reorganisation of the library, have been postponed through lack of funds. The present housing of the institute leaves much to be desired, and it is scarcely creditable to the British, Indian, and Colonial Governments and the large number of officials and colonists throughout the Empire that a decided effort has not been made to place this valuable institution on a sounder footing.

\section{PROBLEMS OF THE ANTARCTIC.}

$\mathrm{NE}$ of the most noteworthy meetings during the Australian session of the British Association was the discussion at Sydney on the past and present relations of Antarctica in their biological, geographical, and geological aspects. The four sections of zoology, geology, geography, and botany held a joint meeting for this purpose on August 25, with Prof. A. Dendy in the chair. Sir Douglas Mawson, who had only reached Sydney the day previously from London, was to open the discussion, but he devoted his time more specially to a general account of the work of the Australian Antarctic Expedition. He expressed his belief in the existence of only one land mass in Antarctica. Prof. T. W. Edgeworth David touched on several points. The uneven level of the ice-barrier at its seaward edge could be adequately explained only by its containing beneath its surface flattened-out ribs of glacier ice from the glacier valleys to the southwest and south-east of the barrier. These would account for the inequalities in level of the barrier face, which varies from 20 to $I_{50} \mathrm{ft}$. above sea-level. In this connection Prof. David pointed out how in the heavily faulted rock strip of South Victoria Land cross faulting had produced low points in the horst through which the inland ice had run. He also dwelt on the importance of the study of Antarctic meteorology in relation to the weather of Australia, and emphasised the value of the Macquarie Island meteorological station.

Mr. Griffith Taylor spoke at some length on glacial erosion. He contended that in $78^{\circ} \mathrm{S}$., the latitude in which his observations were made, there is little or no NO. 2348, VOL. 94$]$ glacial erosion, that it is too cold for it to act, and that the present sculpturing of the land is due to the effects of alternate thawing and freezing. As proof of this theory, he pointed out that the streams flowing from glaciers in summer are clear and not muddy, as, for instance, in the Alps.

Mr. H. T. Ferrar, who was not in entire agreement with Mr. Taylor about erosion, spoke of the tectonics of the continent of Antarctica. $\mathrm{He}$ maintained that the evidence showed that the continent had been under a torsional strain. The Pacific side had fallen and caused the Andean fold while the rest stood firm. Mr. Ferrar agreed with Prof. David about the structure of the great ice-barrier.

Prof. A. Penck brought the discussion back to the main problem. He pointed out the oneness of South Victoria Land with Eastern Australia and the absence of folding since Palæozoic times. On the other hand, Graham Land shows a complete divergence from this structure, and a marked similarity to South America, in its folded beds of Tertiary age and marine origin. The great problem is, How are these two regions of Antarctica, so strikingly opposed to one another, joined? It was formerly suggested that the Andean folds were continuous into Edward Land, but this theory found no support in the geological evidence collected by the Amundsen Expedition in that land. Prof. Penck held that the possibility of a strait across Antarctica was not yet disproved.

Dr. R. N. Rudmose Brown agreed that the main problem of Antarctic exploration was to discover the connection between the two divergent structures of Victoria Land and Graham Land. This would be a justification for a long transcontinental journey like that contemplated by Sir Ernest Shackleton. Dr. Brown disagreed with Prof. Penck as to the existence of a strait across Antarctica, and said that the discoveries of Shackleton and Amundsen in the Ross Sea area and those of Bruce and Filchner, as well as the increased probability of the actual existence of Morrell Land, left no room for such a strait. He pointed out that the Deutschland Expedition has not disproved Morrell Land, but that it had, on the other hand, lent colour to its existence.

Capt. J. K. Davis emphasised the importance of deep-sea work around Antarctica, and gave some account of his own explorations and discoveries south of Tasmania in the Aurora. He pointed out how little of the coast line of Antarctica was known, and insisted that this important part of Antarctic discovery could be more satisfactorily and easily done from sea than by land journeys. Capt. Davis said he wished to place on record his great indebtedness to Dr. W. S. Bruce for the invaluable help he had given him in deep-sea apparatus and advice in its use.

Mr. F. L. Stillwell spoke of the geological work he had done with the Mawson Expedition, and showed specimens of the rocks obtained. He showed that Adelie and Wilkes Land are of the same plateau structure as Victoria Land.

Dr. G. C. Simpson suggested that an area of five million square miles radiating solar energy into space must have an effect on atmospheric circulation which had not so far been given full importance. Dr. Simpson spoke at length on Antarctic meteorology in Melbourne to Section A.

Other speakers included Prof. A. C. Seward and Mr. C. Hedley, and while the discussion cannot be said to have shed much new light on the main problems of Antarctica, it afforded a useful interchange of views and evoked great interest in Sydney. The time proved all too short for the number of speakers available, who were in consequence almost limited to actual explorers.

R. N. Rudmose Brown. 